\title{
Overcriminalization Due To Moral Panic Covid-19 Pandemic
}

\author{
Arif Awaludin ${ }^{1}$, Iskatrinah ${ }^{2}$ \\ 1, 2, Wijayakusuma University, Purwokerto - Indonesia \\ Email: arifawaludin@gmail.com
}

\begin{abstract}
Public health has become the new moral of modern society. The spread of covid-19 pandemic related to public health interests caused moral panic. This article analyzes the discursive process of criminalization in Indonesia. Law enforcement in Indonesia is fighting people who respond to the moral panic of covid-19 pandemic with the threat of criminalization. Using sociolegal methods obtained data derived from media coverage found the fact that there has been an over criminalization of people experiencing moral panic due to the covid-19 pandemic. Various regulations made by the government, both central and regional, have taken a toll. The symbolization of the people's demons is depicted in a single narrative, their appearance and overall identifying too simplified to be easily recognizable. Criminalization also occurs against those who refuse the burial of bodies infected with covid-19, the spread of hoax news, hoarding of consumer goods, misuse of social assistance to violations of quarantine of the region. Victims of law enforcement will continue to fall while the goal of providing awareness related to public health does not materialize. The blurring of the boundaries between the threat of crime and the threat of health indicates the inaccuracy of overcriminalization policies during a pandemic.
\end{abstract}

Keywords- Moral Panic; Overcriminalization; Pandemics

\section{INTRODUCTION}

The State plays a role in realizing welfare and protection for its citizens. In carrying out these obligations the State makes legal devices as its legal foundation. The law is a conscious choice of man to secure his own life. Legal protection is an attempt to organize various interests in society so that there is no inter-interest impact and can enjoy all the rights granted by the law.[1] Organizing is done by limiting one particular interest and giving power to others measurably. Legal protection should also be provided, including in the face of the corona sat pandemic outbreak. The coronavirus outbreak, later referred to by the UN health agency (WHO) as COVID-19 (coronavirus disease that was discovered in 2019), has been emerging since December 2019 with a peak spread in mid-January 2020.[2] The spread of Covid-19 as one of the virus pandemics other than Sars and Bird Flu needs to be understood not only in a medical perspective. It takes a social science perspective and even a law to understand and find a solution. Robert Dingwal states that:[3]

Insights into the discussion of pandemics and infectious diseases in the early 21 st century provide new insights related to evolving social structures and processes. Sociologists are challenged to further contribute to the public and various policy agendas have been criticized as well as questioning narrow thinking that tries to 'leave it all to biomedical science'

The spread of coronavirus outbreak aka covid-19 occurs almost all parts of the world today. Covid-19 has turned the face of the world into fear. No fewer than a hundred and forty countries have been affected by this outbreak of the deadly virus. Some countries were forced to take the decision to designate their country's status as Lockdown Corona. Indonesia does not make such decisions to that status.

The spread of covid-19 outbreak or corona is currently spreading almost all over Indonesia, the government has implemented prevention efforts both by isolating themselves until the discourse of lockdown. The prevention measures taken by the government are a form of efforts to protect their citizens from being infected and break the link of the spread of coronavirus. The latest policy issued by the government through the ministry of health issued a Circular Letter HK.02.01/MENKES/202/ 2020 on The Protocol of Self-Isolation in The Handling of Covid-19.

Some regulations governing the handling of the spread of infectious diseases include Law No. 6 of 2018 on Health Quarantine. Regulation of the Minister of Health No. 82 of 2014, the treatment referred to in the Decree is a health effort that prioritizes promotive and preventive aspects aimed 
at lowering, eliminating pain, disability and death rates and limiting transmission. [4]

Various mass media both print and electronic describe the moral panic of the public towards the outbreak of covid-19 virus in Indonesia. Indonesian Doctor's Association said 25 doctors have died as a result of Covid-19. [5] The stock of masks has been depleted since the Government announced some of the initial policies related to the Corona outbreak. [6] In some countries panic occurs with the purchase of basic goods excessively. [7] Panic also occurred with the phenomenon of rejection of covid-19 patients' funerals such as in Lenteng Agung Jakarta, Gowa South Sulawesi, South Lampung, Makassar to Banyumas Central Java. [8]

The public is very worried about the widespread and contagious outbreak. Moral panic causes various other panics, such as the emergence of the term lock down which is a situation that prohibits citizens from entering a place because of an emergency. The term quarantine means almost the same as isolation, which is to restrict a person from interacting with others. The difference is that quarantine is used for someone who has been exposed to coronavirus but has not shown symptoms of pain. Until the term Social distancing is to reduce the amount of outdoor activity and interaction with others, reducing face-to-face contact. These include avoiding going to crowded places, such as supermarkets, cinemas and stadiums. [9] These terms are actually strategies for tackling the Covid19 outbreak, but in practice they cause tremendous panic among the wider community. Overcriminalization has a more tangible aspect beyond the law and legal theory: for every legal issue, there is always a victim who has a story to tell.

The ongoing criminalization process without being based on a tested assessment and without an evaluation of its effect on the entire system also results in the onset of the crisis of overcriminalization, namely the large or abundant number of crimes and actions criminalized. [10] Overcriminalization is defined as an abundance of crimes and criminalized acts. Overcriminalization arises when the criminalization process continues continuously without being based on a tested assessment and without an evaluation of its effect on the entire system. [11]

\section{PROBLEMS}

The spread of the global Covid-19 virus outbreak has made the virus a pandemic as determined by the WHO (World Health Organization). This spread caused moral panic in society. The moral panic that arises and is recorded in various mass media in both print and electronic, triggering an excessive and potentially unlawful public reaction. Based on this description, several problems arise as follows: first, what is the reality of criminal law enforcement related to the spread of covid-19? And second, has there been overcriminalization in criminal law enforcement during the covid-19 pandemic?

\section{RESEARCH METHOD}

Socio-legal[12] research method is used to obtain information about the current situation, one of the uses of this method is to frame news / information about the law. In this case, various moral panics have occurred due to the covid-19 pandemic and various criminalization cases that have emerged. Socio-law helps to expand the lens of observing law and its daily application. [13]

The research is focused on mass media coverage of the moral panic of the community due to the covid-19 pandemic to over-criminalization in law enforcement. Meticulous mass media coverage from February to July 2020. This study has the first purpose, describing the representation of the news media about moral panic and criminal law enforcement related to the covid-19 outbreak and secondly, analyzing whether there has been over criminalization in criminal law enforcement during the covid-19 pandemic period.

\section{DISCUSSION}

There have been no specific criteria that determine the status of pandemics. Pandemics are also not determined by the number of cases or deaths resulting. However, there are at least three common criteria a disease is said to be pandemic. First, the virus can cause illness or death. Second, the transmission of the virus from person to person continues uncontrolled. Third, the virus has spread to almost the entire world. There have been some of the deadliest pandemic diseases in history such as smallpox, measles, typhoid, spanish flu, black death, HIV/AIDS. [3] 
An agency in the US Department of Health's Centers for Disease Control and Prevention (CDC) notes that pandemics are epidemics that spread to several countries or continents and affect large numbers of people. The term pandemic itself is known in the world of epidemiology or science that studies the pattern of disease spread. In epidemiological dictionaries, plague becomes the least part of disease transmission. Rising from the outbreak, the epidemic signifies a wider range of disease spreads along with rapid transmission. Epidemics can turn into endemics that generally strike one country, region, or continent.

The transmission of covid-19 as a global pandemic was announced on March 11, the number of infections worldwide has reached more than 121,000. [14] Instead of Indonesia still feeling safe from the virus outbreak that has crippled some of the world's countries, President Joko Widodo in early March, who had put people in his comfort zone, had to admit defeat with reports of covid-19 cases caused by the SARS-Cov-2 or better known as the Corona virus.

Covid-19 is a disease identified as the cause of corona virus that attacks the respiratory tract. The disease was first detected in Wuhan, China. SARSCov-2 is not a new type of virus. But in his scientific explanation that a virus is capable of mutating to form new genetic makeup, in short, the virus remains the same type and only changes uniformly. The reason for naming SARS-Cov-2 is because the corona virus is genetically closely related to the viruses that cause SARS and MERS. Slowly, the virus resulted in 8,000 deaths and hundreds of thousands of individuals infected in the first 50 (fifty) days following the chinese government's provision of the infection. Finally, in an instant, the virus spreads to more than 100 (one hundred) countries in the world. [15]

The unprecedented (or never anticipated) spread of the virus will reach Indonesia today. The Bandung Institute of Technology's Mathematics and Simulation Modeling Center predicts that the pandemic will peak at the end of March and end in mid-April 2020. Even with the dynamic of the data, those predictions may change. [16] This data is certainly not to create panic in the community, but rather to make the public alert and provide an overview for the government in its handling. I.e. handling compehensive, especially to prevent a wider spread so that the number of infections can be suppressed.

Here our consciousness should be formed, that viruses as invisible beings always mutate and infect living things. Its spread is not only between one type of living being such as animals to animals or humans to humans but more so its spread lasts from animal to human. Surely we need to take anticipatory measures in order to minimize the spread of diseases that come from animals (zoonoosis) without having to stay away from and wipe animals off the face of the earth. [17]

The Covid-19 pandemic in Indonesia is part of a global pandemic that is ongoing around the world. This disease is caused by severe coronary acute respiratory syndrome 2 (SARS-CoV-2). The first positive cases of Covid-19 in Indonesia were discovered on March 2, 2020, when two people were confirmed to be infected by Japanese citizens.[18] Since 9 April, the pandemic has spread to 34 provinces in Indonesia. Large provinces such as East Java, DKI Jakarta and South Sulawesi are the most exposed provinces. As of 8 July 2020, Indonesia has reported 68,079 positive cases, the most in Southeast Asia surpassing Singapore. In terms of mortality, Indonesia ranks sixth most in Asia with 3,359 deaths. However, the estimated mortality rate is much higher than the data reported. Many of the number of deaths that do not count with acute Covid-19 symptoms because they have not been confirmed or tested. [19] [20] Meanwhile, it was announced 31,585 people had recovered, leaving 33,135 cases being treated.

A. The reality of criminal law enforcement related to the spread of covid-19

The law is a social control tool, including in dealing with covid-19 pandemic. Various laws and regulations are used as tools to control the community. Some of the sentencing cases related to pandemic situations and conditions include:

1. Rejection of covid-19 patients' funerals in many places. The perpetrator was sentenced to 3.5 months in Banyumas [21] and 4 months in Semarang. [22] in violation of Law Number 4 Year 1984 on Infectious Plague.

2. Hoarding masks in Jakarta and Makasar in violation of Law No. 7 of 2014 on Trade. [23] 
3. Violating Law Number 11 of 2008 on Electronic Information and Transactions. As of March 8, 2020, there have been 177 hoaks and disinformation about the coronavirus. Five cases have been reported and dealt with for violating the law. The Director General of APTIKA mentioned that the case of hoaks and disinformation about corona there are as many as 35 cases. Among them are suspect victims, the death toll, the place infected with corona, hoaks that corona is a leaky biological weapon, the spread of certain animals, and so on. [24]

4. Misuse of social assistance there are 102 cases of misappropriation, spread across 20 regional police forces. [25]

5. Forcibly retrieving covid-19 bodies at several hospitals in Makasar, Ambon, [26] Bekasi [27] and Surabaya. [28] The offender was sentenced to 4 months in prison with an 8month probation for violating the Health Quarantine Act. [29]

6. Violation of Regional Quarantine.

Issuance of Indonesian Government Regulation Number 21 of 2020 concerning Large-Scale Social Restrictions. which aims to accelerate the handling of Covid-19. It can be said that this Government Regulation is a further guideline for the implementation of large-scale social restrictions in various regions due to the Covid-19 pandemic Those who violate the ban on crowding will be sanctioned based on:

a. Law Number 6 of 2018, Article 93: anyone who does not comply with the implementation of health quarantine and obstructs the implementation of health quarantine can be sentenced to a maximum of 1 year in prison and / maximum fine of Rp. 100 million.

b. Criminal Code (Penal Code) Article 212, Article 216 to Article 218 of the Criminal Code

6. Do not use masks. Some regions base their criminal sanctions on regulations made by governors, regents or mayors[30] as well as local regulations.

On April 21, 2020, Local Regulations No. 2 of 2020 on The Prevention and Prevention of Disease in Banyumas Regency. Violations for not wearing masks are the most offences committed in Banyumas Regency in May there are 16 people who are subject to criminal sanctions. [31] On June 5, 2020, 46 people were re-tried for not wearing masks. [32] Article 24 of the local regulations states that the obligation for everyone is to wear a mask if they are active outside/in a public room and meet with others; avoid or not perform activities that may invite crowds or may cause crowds. Article 31 paragraph (3) states that: any person who violates is subject to a penalty of Rp 50,000 or a 3-month imprisonment.

B. The Moral Panic Result In Overcriminalization In Criminal Law Enforcement During The Covid-19 Pandemic

Moral panic is a term coined by Stanley Cohen in 1966 to describe the status of his conception and its influence on the study of social reactions to crime. Moral panic can be identified. Not just fear triggered by events, but deeper implications. Panic implies a period of intense reaction, but it is not long or permanent. Moral panic attempts to explain certain types of overreaction to perceived social problems. This terminology was developed in the late 1960s in a turbulent political and intellectual context, its main purpose being to uncover the processes involved in creating concerns about social issues; treatment that has nothing to do with the reality of the problem, but still provides the basis for changes in social or legal codes. [33] The three main problems on which the concept of "moral panic" is based are: normality, temporality and deliberation.

The term 'moral panic' implies that the public reaction is essentially a smokescreen created by the government by manipulating the media and the public agenda. Moral panic is a mechanism for a community to maintain shared values such as: dueness, impression, and so on. If there is a deviation, society has its own mechanism for maintaining this value. [34]

Stanley Cohen, meanwhile, lays the groundwork for the theory of moral panic (morally stating that: [35]

"a condition, episode, person or group emerges to become defined as a threat to societal values and interests; its nature is presented in a stylized and stereotypical fashion 
by the mass media; the moral barricades are manned by editors, bishops, politicians and other right thinking people; socially accredited experts pronounce their diagnosis and solutions; ways of coping are evolved or (more often) resorted to; the condition then disappears, submerges or deteriorates and becomes visible."

People who feel that their values and interests are threatened ultimately define a condition, episode, person or group as a devil. Threats that are formed in the framework of people's thinking because the information they get is always structured. The media and policy makers are the main actors in this shaping process.

Stanley Cohen's concept of moral panic was developed by Erich Goode and Nachman BenYahuda. Moral panic has five distinct characteristics, namely attention, hostility, consensus, disproportionality, and volatility.[36] The behavior, group, or object of the panic is a threat because it raises concern. The existence of hostility towards threats and mutual consensus is a reaction that must be done. Reactions to threats are often felt to be outweighed by the real harm they have caused. [37]

In the theory of moral panic, it always shows a panic response, a systematic and organized response to its opponent that causes panic. According to Erich Goode and Nachman Ben-Yahuda, "There must be a broad agreement or consensus... that the threat is real, serious, and caused by wrongdoing group members and their behavior. [38] Without agreement on the nature and importance of the problem, no force can move against the threat. The moral panic theory also states that the media are very important in providing and disseminating information and fearing the threat claims. It should be noted that before Stanley Cohen, Jock Young in his study had discussed the spiral effect, which is the result of the interaction between the media, public opinion, interested parties, and politics. The combination of all these factors produced what Cohen defined as the phenomenon of moral panic. [39] The media are a means by which to create moral panic: construct threats, inform the public of threats and combat criticism. Ultimately, Jack Young's approach focuses on the role of the media in framing an issue as 'moral panic' and identifying certain social groups as demons of the people and their surroundings [40] Reese provides a definition of an overarching framework: The frame is an organizing principle that is shared socially and persists over time, working symbolically to constitute a meaningful social world. [41]

Since its inception, the concept of moral panic has been applied to a variety of social problems including but not limited to youth gangs, violence in schools, child abuse, Satanism, illegal logging and various actions that cause concern to society. In this case, moral panic could result from the Covid-19 pandemic. This pandemic is fundamentally a public health problem. Lack of information and the emergence of various public policies that are very unsettling and detrimental to society are ways to create moral panic.

The essence of the concept of moral panic is the reason that public concern or fear of social issues will benefit state officials - such as politicians and law enforcement officials - as well as the mass media. The relationship between state officials and the media is symbiotic mutualism, mutually beneficial. Where politicians and law enforcers need communication channels to distribute their rhetoric and the media need news content that can attract public attention which will eventually attract advertisers.

Moral panic arises when distorted mass media coverage is used to create fear, reinforce stereotypes and exacerbate long-standing divisions in the world. These stereotypes are often based on race, ethnicity and social class. Moral panic has three distinguishing features. First, attention is focused on the behavior, both real and imagined, of a particular individual or group. Cohen described this behavior as the "devil of the people". The media separates Satan from all favorable characteristics and applies them with negative characteristics. Second, there is a gap between concern for a condition and the objective threats it poses. Typically, objective threats are much smaller than those popularized and presented by the authorities. Third, there is a lot of fluctuation from time to time in the level of attention to a condition. This pattern begins with the discovery of a threat, is followed by a rapid increase and then peaks in public attention, and often suddenly, subsides. [42]

In the case of covid-19 pandemic in Indonesia there is a moral panic caused by the following:

1. Inability to detect covid-19 profile that plagues Indonesia 
Although COVID-19 began to enter Indonesia in early March 2020, its prevention campaign began to be launched from DecemberJanuary, the Government still uses the name "Chinese Pneumonia" to refer to COVID-19. So it is clear that Covid-19 is not entering Indonesia. Health experts worry that Indonesia unable to identify the mode of transmission of the virus. [43] Marc Lipsitch, professor of epidemiology at Harvard University analyzed aircraft traffic from China and concluded that Indonesia may have had a missed case. Western countries as well as local [44] and international [45] mass media concluded that the absence of cases of covid-19 transmission in Indonesia was due to inadequate testing and under-reporting, rather than mere luck.

2. The government is less open

Indonesian President Joko Widodo was also criticized by the Indonesian Chamber of Commerce and Industry[46], the National Commission on Human Rights, [48] and also by political parties [49] [50]for their lack of openness about COVID-19 information. Jokowi insisted on not sharing details of the patient's travel history with positive coronary virus test results to reduce panic and anxiety of the general public. [51] However, the confidentiality of this information is still considered unlawful. Criticism of data disclosure was also conveyed by indonesian doctor's association (IDI) regarding how many medical personnel are positive covid-19. The public has asked the government to release an official national map of the locations of confirmed cases of Covid-19 transmission, because the existence of an unofficial independent map can provide false data. [52]

3. Lack of Health Facilities

Many reports of patients in the Jakarta and surrounding areas having to wait a long time to get tests or treatment because of the possibility of contracting Covid-19. Referral hospitals face increasing pressure. The number of health workers is uneven and disproportionate. [53]

4. Chaotic Government Policy

On March 27, Indonesian medical professors asked the government to quarantine the local area, stating that the government's policy of physical exterminating was ineffective. The government is drafting a government regulation to regulate procedures and conditions for implementing regional quarantines.[54] The policy of banning homecoming for all citizens was issued by the government after the widespread spread of the virus. On April 21, 2020, President Joko Widodo said that the government would ban eid mudik for all citizens in the red zone area of virus transmission. On March 30, 2020, President Jokowi acknowledged that there has been an acceleration of homecoming flow. "Since the establishment of emergency response in DKI Jakarta, there has been an acceleration of homecoming flow, especially from informal workers in Jabodetabek to West Java Province, Central Java Province, and DIY, as well as to East Java," President Jokowi said in a limited meeting broadcast live. [55]

Various policies made by the government ranging from regional quarantine affairs, health equipment import policy, homecoming determination during the holiday, the arrival of foreign workers, to the policy of providing incentives for health workers to benefits for people affected by Covid 19 cause chaos. Uncoordinated, sectoral egos and less responsive work seem to be presented before society. As a result, trust in the government declined. The criminalization of people experiencing moral panic over the covid-19 pandemic is beyond state control. The symbolization of the people's demons is depicted in a single narrative, their appearance and overall identifying too simplified to be easily recognizable. Criminalization also occurs against those who refuse the burial of bodies infected with covid19, the spread of hoax news, hoarding of consumer goods, misuse of social assistance to violations of quarantine of the region. Moral panic is seen as invisible. This rhetoric links border violations to criminal activity; emphasize the potential for violence buried by those experiencing moral panic; and blur the line between the threat of crime and the threat of health. Until the over-criminalization occurred.

Overcriminalization is a term first popularized by Kadish in 1968. [56] Overcriminalization is defined as the use of criminal law to realize public policy objectives 
that are completely unworthy/unjustified to be prohibited. [57] Overcriminalization is manifested in a number of ways, such as defining crimes that are too broad, penalties that are too harsh, and criminal sanctions for simple mistakes or problems. In fact, overcriminalization has a more tangible aspect beyond the law and legal theory: For every problematic law, victims have a story to tell.

Epidemics and pandemics threaten the health and well-being of society, and thus justify the expansion of police power which, under ordinary circumstances, constitutes an intolerable violation of individual liberty. Criminal sanctions, while sometimes necessary, are a blunt instrument and a generally unwelcome approach to advancing public policy objectives; Criminal sanctions, while sometimes necessary, are a blunt instrument and a generally unwelcome approach to advancing public policy objectives.

The imposition of criminal sanctions may only be imposed if civil or administrative sanctions fail to result in compliance with executive orders and are no more than necessary to fulfill the basic objectives of criminal justice. These goals are generally described as disability, prevention, rehabilitation and retribution. [58]

The expansion of police power during a pandemic must be subject to reasonable limits, namely: [59]

1. Policies should only be implemented during a pandemic, and the government must provide reasonable benchmarks against which a pandemic is ending.

2. The freedom arrangement should be limited as much as possible.

3. If civil or administrative sanctions fail, then criminal sanctions can be applied.

Overcriminalization is a phenomenon in which the state, through its law enforcement, criminalizes too many acts and punishes too many people. The problem is not that simple, and the application of the concept of criminalization requires normative evaluation not mere description. However, no one believes that overcriminalization is a good policy option.. [60]

On another occasion Ashworth argued that, contrary to Sanford H. Kadish's thinking, criminalization and criminal law were not the only instruments in order to regulate the conduct of legal subjects. Ashworth's thesis on overcriminalization is that it goes beyond the true function of criminal law because legislators ignore the distinction between criminal law and other statutory regulations. Ashworth states:

It is felt that criminal law is not the only option in a series of techniques available to legislatures to regulate human behavior and activities. Various regulatory regimes are now offering. From licensing to franchising, from financial regulations to environmental standards and so on. Most modern democracies include a number of legal regulatory bodies, which are tasked with regulating specific activities. Civil law also regulates behavior in many ways, although it usually leaves it up to the aggrieved party to initiate enforcement action.[61]

Ashworth's opinion is interesting because it associates criminalization (criminal law) with other areas of law that in essence have the same nature or character that is to regulate the actions of the subject of the law. Associated with the enactment of other areas of law as an instrument for the state to make arrangements then the opinion of the Ashworth can mean that the criminalization of an act is ultimum remedium. If it is the other way around, then the criminalization should be judged as an overcriminalization effort. The scholar who specifically used the concept of excessive criminalization as an unauthorised criminalization was Douglas Husak. The concept of excessive criminalization is used by Husak to describe the phenomenon of too many criminal threats made by the state against its citizens. [62] Husak's target is to produce a criminalization theory, namely: a normative framework to separate between justified and unjustified criminal law. [63] Husak argued is essentially a response to a phenomenon in the United States that he thinks: . We are overpunished and overcriminalize. The point of view of Husak's theory is criminalization and Criminal Law is ultimum remedium. Therefore there are limits to whether an action can be criminalized, so that in the end whether it is worthy of being the object of criminal law or not.

\section{CONCLUSION}


Overcriminalization is not the solution in controlling society due to moral panic caused by the covid-19 pandemic outbreak. Overcriminalization has the potential to violate human rights. Imprisonment is not an educational solution. Justice reinvestment advocates that, funding for prisons should be reduced and redirected towards addressing the underlying causes of crime in communities with high levels of incarceration. Incarcerated individuals over whelmingly come from the poorest and marginalized sectors of society. There is a need for a reinvestment of justice by proposing a diversion of resources from detention to prevention, early intervention and rehabilitation of disadvantaged communities that need care and attention. Another effective way of dealing with the problem of overcriminalization is the decriminalization of guilt that is harmless and does not conflict with personal morality. Such errors must be excluded from the scope of the definition of crime. [65] This paper emphasizes the need to decriminalize victimless crime. Victimless crime refers to illegal behavior that does not violate or threaten anyone's rights. The goal of the criminal justice system is to do justice by punishing criminals. The decriminalization of minor mistakes such as wrongdoing against personal morality will enable the criminal justice system to do its primary job of protecting people and property from serious crime.

\section{ACKNOWLEDGEMENT}

Thank you to the Faculty of Law of Wijayakusuma Purwokerto University who have facilitated this research activity and to colleagues and team members who helped with the idea and completion of this research and paper.

\section{REFERENCES}

[1] S. Raharjo. Ilmu Hukum, Bandung: PT. Citra Aditya Bakti, 2000.

[2] News, "Pemerintah Sangat Terlambat Menangani Wabah Covid-19", TAGAR, 2020. [Online]. Available: https://www.tagar.id/pemerintah-sangatterlambat-menangani-wabah-covid19, 2020.
[3] R. Dingwall, L. Hoffman and K. Staniland, "Introduction: why a Sociology of Pandemics?", Sociology of Health \& Illness, vol. 35, no. 2, pp. 167-173, 2012.

[4] "Cerdas Mencerahkan - Pijar News", Pijarnews.com, 2020. [Online]. Available: https://www.pijarnews.com/opinimelindungi-warga-negara-melaluiregulasi-dari-ancaman-wabah-covid-19/2. [Accessed: 01- Apr- 2020]

[5] Suara.com, 2020. [Online]. Available: https://www.suara.com/health/2020/04/04 /194946/ kabar-duka-idi-sebut-25-doktermeninggal-akibat-virus-corona-covid-19. [Accessed: 05- Apr- 2020]

[6] Regional Kompas, 2020. "Stok Masker habis virus corona bisa dicegah dengan PHBS" [Online] Available: https://regional.kompas.com/read/2020/0 3/03/ 16000041/stok-masker-habis-viruscorona-bisa-dicegah-dengan-phbs

[Accessed March 20, 2020]

[7] E. Saputra, "Virus Corona Memburuk, Inggris dan Australia Dilanda Panic Buying", Tempo, 2020. [Online]. Available: https://dunia.tempo.co/read/1321437/viru s-corona-memburuk-inggris-danaustralia-dilanda-panic-buying.

[Accessed: 23- Mar- 2020]

[8] Regional Kompas, "Ini sederet alas an warga diberbagai daerah tolak pemakaman jenzah korban" [Online] Available:

https://regional.kompas.com/read/2020/0 4/05/0617 0031/ini-sederet-alasan-wargadi-berbagai-daerah-tolak-pemakamanjenazah-korban?page $=3$ [Accessed Apr, 23, 2020]

[9] Arti Lockdown, Social Distancing, dan Istilah Corona Lainnya", suara.com, 2020. [Online]. Available: https://www.suara.com/news/2020/03/18/ 105643/arti-lockdown-social-distancing- 
dan-istilah-corona-lainnya. [Accessed: 18- Mar- 2020]

[10]Bassiouni,, M. Sherif. Substantive Criminal Law, Springfield: Charles Thomas Publisher, 1978

[11]A.B Nawawi. Bunga Rampai Kebijakan Hukum Pidana, Cetakan Ketiga, Edisi Revisi, PT. Citra Aditya Bakti, 2005.

[12]B. Tamanaha, "The Internal/External Distinction and the Notion of a "Practice" in Legal Theory and Sociolegal Studies", Law \& Society Review, vol. 30, no. 1, p. 163, 1996.

[13] "Law and legal studies", The British Library, 2020. [Online]. Available: http://www.bl.uk/reshelp/findhelpsubject/ busmanlaw/legalstudies/soclegal/socioleg al.html. [Accessed: 10-March- 2020]

[14] World Health Organization, WHO Director-General's opening remarks at the media briefing on COVID-(1). [Online]

Available: https://www.who.int/dg/ speeches/ detail/ who-director-general-sopening-remarks-at-the-media-briefingon-covid-19. [Accessed: 11-march-2020]

[15] M. Shereen, S. Khan, A. Kazmi, N. Bashir and R. Siddique, "COVID-19 infection: Origin, transmission, and characteristics of human coronaviruses", Journal of Advanced Research, vol. 24, pp. 91-98, 2020 .

[16] C. Indonesia, "ITB: Puncak Corona RI Akhir Maret, Berakhir Tengah April 2020", teknologi, 2020. [Online]. Available:

https://www.cnnindonesia.com/teknologi/ 20200319142837-199-484974/itb-

puncak-corona-ri-akhir-maret-berakhirtengah-april-2020. [Accessed: 11- Mar2020]

[17] R. D'amore, "Coronavirus: Where did it come from and how did we get here?",
Global News, 2020. [Online]. Available: https://globalnews.ca/news/6682629/coro navirus-how-did-it-start/. [Accessed: 11Mar- 2020]

[18]R. Ratcliffe, "First coronavirus cases confirmed in Indonesia amid fears nation is ill-prepared for outbreak", the Guardian, 2020. [Online]. Available: https://www.theguardian.com/world/2020 /mar/02/first-coronavirus-casesconfirmed-in-indonesia-amid-fearsnation-is-ill-prepared-for-outbreak. [Accessed: 11- Mar- 2020]

[19] K. Tom Allard, "Exclusive: More than 2,200 Indonesians have died with coronavirus symptoms, data shows", U.S., 2020. [Online]. Available: https://www.reuters.com/article/ushealth-coronavirus-indonesia-casualtiidUSKCN22A04N. [Accessed: 11- Mar2020]

[20] K. Media, "Ahli Kesehatan Prediksi Jumlah Kematian karena Covid-19 di AS Lebih dari 410.000 pada 2021", KOMPAS.com, 2020. [Online]. Available:

https://www.kompas.com/global/read/202 0/09/05/050000470/ahli-kesehatanprediksi-jumlah-kematian-karena-covid19-di-as-lebih-dari. [Accessed: 25- May2020]

[21] Regional Kompas, "PNS Penolak Pemakaman Jenazah Covid-19 di Banyumas di Vonis 35 bulan penjara' [Online] Available: https://regional.kompas.com/read/2020/0 8/06/ 14391261/pns-penolakpemakaman-jenazah-covid-19-dibanyumas-divonis-35-bulan-penjara, August, 06, 2020,_[Accessed August 10, 2020]

[22] Suara "3 Penolak Jenazah Perawat Positif Corona di Semarang Dipenjara 4 Bulan", suara.com, 2020. [Online]. Available: https://jateng.suara.com/read/2020/07/27/ 185831/3-penolak-jenazah-perawat- 
positif-corona-di-semarang-dipenjara-4bulan. [Accessed: 10- Aug- 2020]

[23]I. Hafid, "Penegakan Hukum atas Penimbunan Masker", detiknews, 2020. [Online]. Available: https://news.detik.com/kolom/d4924942/penegakan-hukum-ataspenimbunan-masker. [Accessed: 01- Aug2020]

[24]"Lima Kasus Hoaks Corona Telah Dilaporkan", Ditjen Aptika, 2020. [Online]. Available: https://aptika.kominfo.go.id/2020/03/lima -kasus-hoaks-corona-telah-dilaporkan/.

[Accessed: 25- July- 2020]

[25] S. Persada, "Mabes Polri Catat 102 Kasus Dugaan Penyelewengan Bansos Covid19", Tempo, 2020. [Online]. Available: https://nasional.tempo.co/read/1369886/ mabes-polri-catat-102-kasus-dugaanpenyelewengan-bansos-covid19/full\&view=ok access on August 01, 2020. [Accessed: 25- Jul- 2020]

[26] Y. Dahono, Insiden Pengambilan Paksa Jenazah Covid-19 11 orang jadi tersangka. [Online]. Available: https://www.beritasatu.com/yudodahono/nasional/649903/insidenpengambilan-paksa-jenazah-covid19-11orang-jadi-tersangka. [Accessed: 28- Jul2020]

[27] Benar News. Pengambilan paksa Jenazah Covid. [Online] Available: https://www.benarnews.org/indonesian/b erita/covid-19-pengambilan-paksajenazah-06122020133843.html

[Accessed: 28-July-2020]

[28] Republika, "Pengambilan Paksa Jenazah Terjadi Lagi | Republika ID", republika.id, 2020. [Online]. Available: https://www.republika.id/posts/7365/ pengambilan-paksa-jenazah-terjadi-lagi. [Accessed: 28- July- 2020]
[29] Liputan 6, "Berita vonis pengambil paksa jenazah covid-19 Hari Ini - Kabar Terbaru Terkini | Liputan6.com", Liputan6.com, 2020. [Online]. Available: https://www.liputan6.com/tag/vonispengambil-paksa-jenazah-covid-19. [Accessed: 28- Jul- 2020]

[30]Kompas, “6 Daerah yang berlakukan denda bagi mereka yang tidak pakai masker" [Online] Available: https://www.kompas.com/tren/read/2020/ 07/24/ 092800865/6-daerah-yangberlakukan-denda-bagi-mereka-yang-takpakai-masker?page $=$ all $\quad$ [Accessed 01August-2020]

[31]"Tidak Pakai Masker, 15 Warga Banyumas Disidang dan Didenda Rp 10.000 merdeka.com", merdeka.com, 2020. [Online]. Available: https://www.merdeka.com/peristiwa/tidak -pakai-masker-15-warga-banyumasdisidang-dan-didenda-rp-10000.html. [Accessed: 01- Aug- 2020]

[32] Tribun News, "Tribun banyumas - Berita Terkini banyumas", Tribun banyumas, 2020. [Online]. Available: https://banyumas.tribunnews.com/2020/0 6/05/ masih-saja-ada-warga-tak-gunakanmasker-di-banyumas-jalani-sidangtipiring-didenda-rp-15-ribu. [Accessed: 01- Aug- 2020]

[33] A. Rohloff and S. Wright, "Moral Panic and Social Theory", Current Sociology, vol. 58 , no. 3 , pp. 403-419, 2010.

[34] Eriyanto, Analisis Naratif: Dasar-dasar dan Penerapannya dalam Anallisis Teks Berita Media, Jakarta: Kencana, 2013.

[35] S. Cohen, Folk Devils and Moral Panics: The Creation of the Mods and Rockers. Oxford: M. Robertson, 1980

[36]Ben-Yehuda. and E. Goode, Moral Panics. Oxford: John Wiley \& Sons, 2010. 
[37] A. Hill, "This Modern Day Slavery". Berkeley, CA: University of California, 2011.,

[38]Ben-Yehuda. and E. Goode, Moral Panics. Oxford: John Wiley \& Sons, 2010

[39]J. Young, The drugtakers. London: Paladin, 1972.

[40]M. Flinders, "The demonisation of politicians: moral panics, folk devils and MPs' expenses", Contemporary Politics, vol. 18, no. 1, pp. 1-17, 2012.

[41] M. Linstrõm and W. Marais, "Qualitative news frame analysis: a methodology", Journals.ufs.ac.za, 2020. [Online]. Available: http://journals.ufs.ac.za/index.php/ com/article/view/991. [Accessed: 01Aug- 2020]

[42] W. Deeds, "Moral Panic: Who Benefits From Public Fear?", Psychology Today, 2020. [Online]. Available: https://www.psychologytoday.com/ie/blo g/wicked-deeds/201507/moral-panicwho-benefits-public-fear. [Accessed: 01Aug- 2020]

[43] S. Sidik, "1 Pegawai Bank Permata di Kantor Pusat WTC II Positif Corona", market, 2020. [Online]. Available: https://www.cnbcindonesia.com/market/2 0200320133313-17-146437/1-pegawaibank-permata-di-kantor-pusat-wtc-iipositif-corona. [Accessed: 25- Mar- 2020]

[44] T. Post, "Let's not kid ourselves. Indonesia is unlikely to be COVID-19free. And that's not our biggest problem.", The Jakarta Post, 2020. [Online]. Available:

https://www.thejakartapost.com/academia /2020/02/29/lets-not-kid-ourselvesindonesia-is-unlikely-to-be-covid-19free-and-thats-not-our-biggestproblem.html. [Accessed: 26- Mar- 2020]
[45] K. McVeigh and E. Graham-Harrison, "Academic stands by research querying Indonesia's claim to be coronavirusfree", the Guardian, 2020. [Online]. Available:

https://www.theguardian.com/world/2020 /feb/14/indonesia-coronavirus-academicharvard-marc-lipsitch. [Accessed: 27Mar- 2020]

[46]B. Satu, "We Don't Cover Things Up, Indonesia Says Amid Doubts Over Its Covid-19 Handling", Jakarta Globe, 2020. [Online]. Available: https://jakartaglobe.id/news/we-dontcover-things-up-indonesia-says-amiddoubts-over-its-covid19-handling. [Accessed: 25- Mar- 2020].

[47]L. Barron, "Experts Fear Coronavirus Going Undetected in Southeast Asia", Time, 2020. [Online]. Available: https://time.com/5792180/southeast-asiaundetected-coronavirus/. [Accessed: 30Mar- 2020]

[48] Da Costa, Agustinus Beo.. Indonesia says lack of COVID-19 cases a blessing from God, 2020.

[49]R. Ratcliffe, "Indonesia's hidden coronavirus cases threaten to overwhelm hospitals", the Guardian, 2020. [Online]. Available:

https:/www.theguardian.com/globaldevelopment/2020/mar/26/indonesiacould-have-thousands-of-hiddencoronavirus-cases-study-says. [Accessed: 29- Mar- 2020]

[50]T. Yuniatno, "Cegah Kepanikan, Pengusaha Minta Pemerintah Jujur Soal Virus Corona - Nasional Katadata.co.id", Katadata.co.id, 2020. [Online]. Available: https://katadata.co.id/ameidyonasution/be rita/5e9a470dab9b5/cegah-kepanikanpengusaha-minta-pemerintah-jujur-soalvirus-corona. [Accessed: 05- March2020] 
[51]C. Indonesia, "Pengamat Desak Peta Covid-19 Nasional: Mudah dan Tak Mahal", teknologi, 2020. [Online]. Available:

https://www.cnnindonesia.com/teknologi/ 20200317193251-185-484321/pengamatdesak-peta-covid-19-nasional-mudahdan-tak-mahal. [Accessed: 28- Mar- 2020]

[52]G. Cahya and S. Atika, "'It was too crowded': Patients find it hard to get COVID-19 tests, treatment", The Jakarta Post, 2020. [Online]. Available: https://www.thejakartapost.com/news/20 20/03/18/it-was-too-crowded-patientsfind-it-hard-to-get-covid-19-teststreatment.html. [Accessed: 20- Mar2020]

[53] K. Media, "Pemerintah Tak Larang Mudik Lebaran, tetapi Ada Syaratnya", KOMPAS.com, 2020. [Online]. Available: https://nasional.kompas.com/read/2020/0 4/02/12245691/pemerintah-tak-larangmudik-lebaran-tetapi-ada-syaratnya.

[Accessed: 28- July- 2020]

[54]Liputan 6, "Keputusan Jokowi Larang Mudik Sangat Terlambat", liputan6.com, 2020. [Online]. Available: https://www.liputan6.com/bisnis/read/423 3340/keputusan-jokowi-larang-mudiksangat-terlambat. [Accessed: 28- Jul2020]

[55] Kadish, Sanford H. "The Crisis of Overcriminalization", American Criminal Law Quarterly, 1986

[56] M. BuchhandlerRaphael, Overcriminalizing speech. [New York, N.Y.]: Cardozo Law Review, 2015.

[57]A. Duff and Z. Hoskins, "Legal Punishment (Stanford Encyclopedia of Philosophy)", Plato.stanford.edu, 2020. [Online]. Available: https://plato.stanford.edu/entries/legalpunishment/. [Accessed: 28- Mar- 2020]
[58] "Resolution on Over Criminalization and Pandemics - American Legislative Exchange Council", Alec.org, 2020. [Online]. Available: https://www.alec.org/modelpolicy/resolution-on-overcriminalization-and-pandemics/. [Accessed: 09- Aug- 2020]

[59][D. Husak, "Overcriminalization", International Encyclopedia of Ethics, pp. 1-8, 2019.

[60] Andrew Ashworth, Conceptions of Over Criminalization. Ohio State Criminal Law Journal, Vol. 5, 407, 408, 2008

[61]D. Husak, Overcriminalization. New York: Oxford University Press, 2010.

[62][D. Husak, Overcriminalization. New York: Oxford University Press, 2010.

[63] R. Panta, "Over Criminalization and its Effects on the Criminal Justice System" Acclaims. Vol 6, July, pp. 1-9, 2019 